\title{
Effect of Age, Sex and Pregnancy on Levels of Urinary Inhibitors of
}

\section{mineralization in Human Beings}

Kakkar M1, Kakkar R², Lal AK³ ${ }^{3}$ Singla SK ${ }^{4}$

${ }^{1}$ Associate Professor, Department of Biochemistry, Himalayan Institute of Medical Sciences,

Dehradun, India.

${ }^{2}$ Professor, Department of Community Medicine, Himalayan Institute of Medical Sciences,

Dehradun, India.

3Professor, Department of Biochemistry, Himalayan Institute of Medical Sciences, Dehradun, India.

${ }^{4}$ Professor, Department of Biochemistry, Punjab University, Chandigarh, India.

\section{Chief Editor}

\section{Dr. Brijesh Sathian}

\section{Technical Editor}

Dr. Nishida Chandrasekharan

Formatting Editor

Dr. Brijesh Sathian

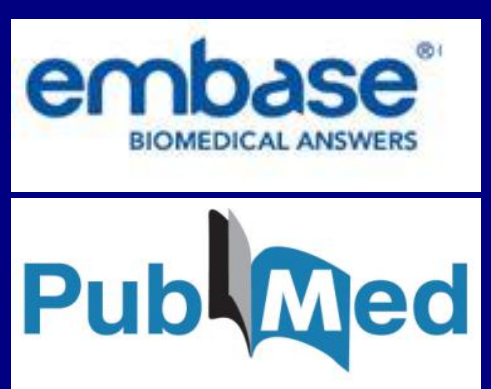

This title

is indexed

in SciVerse

Scopus

Improving research

results through

analytical power

\section{Original Article}

\section{Corresponding Author}

Dr.Monica Kakkar MD

Associate Professor, Department of Biochemistry,

Himalayan Institute of Medical Sciences,

S R H University, Swami Ram Nagar, Jolly Grant,

Dehradun, India.

E-mail: drmonica7@rediffmail.com

\section{Abstract}

\section{Background}

Based upon the differences observed in the level of urinary inhibitors between adult normal subjects of both sexes and kidney stone patients of identical sex, it has been postulated that urinary inhibitors play an important role in the control of pathological mineralization. Review of literature revealed that corresponding studies on the level of urinary inhibitors in children of both sexes and during various stages of pregnancy are not available. These studies, so important to investigate the role of inhibitors in physiological mineralization, formed the objective of the present study.

\section{Materials and Methods}

Homogenous system of In vitro mineralization was employed to study not only the extend of mineralization and the effect of various urine samples obtained from normal subjects of both sexes and pregnant females at various trimesters of pregnancy on extend of mineralization but also to quantify the level of the inhibitors.

\section{Results}

Using in vitro system of mineralization (precipitation of $\mathrm{Ca}^{2+}$ or $\mathrm{HPO}_{4}{ }^{2-}$ ions as mineral phase), it has been shown that in contrast to the adult human beings, in children of 
less than 13 years of age no significant differences exists in the level of the urinary inhibitors between males and females children provided experimental support to the epidemiological studies on the occurrence of the renal calculosis problem in both sexes of children and adult human beings. The findings that the level of the urinary inhibitors of mineralization in both sexes of children is as high as present in adult females and that a highly significant decrease in their levels occurs during the $3^{\text {rd }}$ trimester of pregnancy strongly suggests that hormones may be playing an important role in regulating their levels.

\section{Conclusion}

Inhibitors of mineralization excreted in urine of normal healthy subjects of both sexes of Children ( $<13$ years), adults ( $>20$ years), kidney stone patients at these ages, non pregnant and pregnant females (during various trimesters of pregnancy) have been postulated to play an important role in the control of both physiological and pathological mineralization.

Key words: Mineralization, Renal Calculosis, Urinary Inhibitors and Mineral Phase.

\section{Background}

In man and other vertebrates, mineral phase has been found to be associated with bone collagen, enamel protein, aortic elastin or matrix vesicles. The mineralization of bone and teeth is a physiological phenomenon, where as mineralization of aorta, urinary or salivary system is known to occur under specific pathological conditions ${ }^{1-4}$.

Renal calculosis is a multi-factorial problem which initiates with the formation of micro-crystals in urine \& terminates with the formation of a mature calculus in the kidneys ${ }^{5}$. Out of many intrinsic \& extrinsic factors postulated to be involved in the etiology of renal calculosis, various inhibitors of mineralization (formation of mineral phase from constituent ions) present in urine, serum \& other body fluids have been postulated to play an important role in the etiopathogenesis of renal calculosis ${ }^{6}$. The inhibitors have been shown to be both cationic and anionic in nature having molecular weights between less than 100 to greater than few thousands Daltons ${ }^{7-13}$.

Based upon the studies that qualitative and quantitative differences exist in the urinary inhibitors between male and female sexes of normal human beings and between normal subjects and kidney stone patients of identical sex, a role has been assigned to the urinary inhibitors in the etiology of renal calculosis ${ }^{14-17}$. Studies have further shown that the above differences in urinary inhibitors between normal adult male and female subjects or normal and kidney stone patients of identical sex are primarily due to the differences in the polypeptides having molecular weights between 2-12 thousand Daltons ${ }^{18}$. Interestingly, in contrast to adult human beings, where males have been found to be at least three times more prone to renal calculosis as compared to adult females, equal tendency of renal calculosis has been reported in males and females during their childhood ${ }^{19-20}$.
Age, Sex and Pregnancy on Levels of Urinary Inhibitors
Isolation of the polypeptide inhibitors of mineralization from collagenous tissues (flexor tendons and thoracic aorta) which normally do not get mineralized under physiological conditions but get mineralized only under specific pathological conditions prompted scientists to suggest that the above inhibitors of mineralization may be playing an important role in the control of both pathological and physiological mineralization processes ${ }^{21}$.

Review of literature revealed that no study on inhibitors of mineralization has yet been conducted either in children or adult pregnant females during different stages of pregnancy. The present studies were thus planned to determine the level of the urinary inhibitors in children of both sexes (up to 13 years) and pregnant females (> 20 years of age) at various stages of pregnancy and compare these with the results already available in literature on adult male and non-pregnant adult females.

\section{Material and Methods}

\section{Study design and the participants:}

This study was a cross sectional study which was conducted at Himalayan Institute of Medical Sciences, Dehradun, India, a tertiary care hospital situated in Uttarakhand.

\section{Data collection:}

The data was collected over a period of one year from 1st September 2009 to 30th August 2010 from the normal subjects visiting the hospital, fulfilling the inclusion criteria. A detailed history, including personal, past, family history, symptoms related to urolithiasis and general examination was recorded with the consent of the subjects in the predesigned proforma.

\section{Inclusion criteria:}

Clinically healthy male and female children $(<13$ years of age), non pregnant females ( $>20$ years of age), pregnant females in $1^{\text {st }}, 2^{\text {nd }}$ and $3^{\text {rd }}$ trimester of pregnancy without any history of ever suffering from any disorder effecting mineral metabolism.

\section{Exclusion criteria:}

Male and female subjects suffering or having any history of suffering from either mineral metabolism disorders, calculosis affecting any tissue or any renal ailment were excluded from the studies.

\section{Sample size calculation:}

In the absence of previous published data all samples available during the study were considered as a sample. It was assumed that in age group $<13 \mathrm{yrs}$, the characteristics are homogenous, so a small sample size is enough to represent the population. 60 male and female children each ( $<13$ years of age), 25 non pregnant females ( $>20$ years of age) and 25 pregnant females each in $1^{\text {st }}, 2^{\text {nd }}$ and $3^{\text {rd }}$ trimester of pregnancy were selected for the present study.

\section{Outcome Variable:}

The main outcome variable was the level of the urinary inhibitors of mineralization.

\section{Explanatory variables:}

Factors which were taken into consideration were Age $(<13$ years and $>20$ years), gender (male and female) $, 1^{\text {st }}, 2^{\text {nd }}, 3^{\text {rd }}$ trimester pregnant females. 
Homogenous system of in vitro mineralization:

The reaction system consisted of $5 \mathrm{mM} \mathrm{CaCl}_{2}, 5 \mathrm{mM}$ $\mathrm{KH}_{2} \mathrm{PO}_{4}, 87.5 \mathrm{mM}$ Tris- $\mathrm{HCl}$ Buffer $(\mathrm{pH} 7.4)$ and $105 \mathrm{mM}$ $\mathrm{NaCl}$, in a final volume of $5.0 \mathrm{ml}$. The $\mathrm{pH}$ of the solutions added to the reaction was pre-adjusted to 7.4. To obtain precipitation, the reaction tubes were incubated for 10-12 $\min$ at $37^{\circ} \mathrm{C}$. The supernatants obtained were discarded and the precipitates thus formed were dissolved in $5.0 \mathrm{ml}$ of 0.1 $\mathrm{N} \mathrm{HCl}$ and the concentration of calcium and phosphate in these samples were determined by methods of Baginski, Marie, Clark and $\mathrm{Zak}^{22}$ and Amador and Urban ${ }^{23}$ respectively.

\section{Effect of Urine samples on in vitro Mineralization:}

Various amounts of urine samples obtained from children ( $<13$ years of age) of both sexes and pregnant females (during three trimesters of pregnancy) were added in the reaction system in order to determine their effect on in vitro mineralization. The $\mathrm{pH}$ of the urine samples was preadjusted to 7.4 before addition to the various reaction systems. Percent inhibition of $\mathrm{Ca}^{2+}$ or $\mathrm{HPO}_{4}{ }^{2-}$ precipitation as mineral phase caused by a given amount of urine sample was calculated w.r.t the control system where identical amounts of distilled water were added.

Ethical committee approval:

Prior the study, ethical committee approval was taken from the institutional ethical committee, Himalayan Institute of Medical Sciences, Dehradun, India.

Data management and statistical analysis:

The data collected was analyzed using Excel 2007, Statistical Package for the Social Sciences (SPSS) for Windows Version 16.0 and EPI Info 3.5.1 Windows Version. Chi square test was used to observe the difference between different variables and strength of the relationship. $p<0.05$ was considered as statistically significant.

\section{Result:}

Level of urinary inhibitors in male and female children of $<13$ years of age:

In vitro system of $\mathrm{Ca}^{2+}$ and $\mathrm{HPO}_{4}{ }^{2-}$ precipitation as mineral phase resembling hydroxyapatite in nature was used to investigate the ability of various urine samples obtained from children of both sexes and pregnant females during the three trimesters of pregnancy to influence the formation of mineral phase from its constituent ions under physiological conditions of temperature, $\mathrm{pH}$ and ionic strength of the media.

Results presented in Table-1, demonstrate that human urine contains biomolecules which act as potent inhibitors of in vitro precipitation of $\mathrm{Ca}^{2+}$ and $\mathrm{HPO}_{4}{ }^{2-}$ ions as mineral phase. Addition of $0.1,0.2,0.3,0.4,0.5,0.6$ or $0.7 \mathrm{ml}$ of urine samples from female children between 7-13 years of age were found to inhibit the precipitation of $\mathrm{Ca}^{2+}$ and $\mathrm{HPO}_{4}$

${ }^{2-}$ ions as mineral phase by $17.40 \pm 2.34,30.54 \pm 4.32,46.34$ $\pm 4,78,56.87 \pm 6.98,68.54 \pm 6.35,88.45 \pm 7.21$ or $92.12 \pm$ 8.65 and $14.82 \pm 1.98,28.21 \pm 2.65,43.78 \pm 4.39,54.21 \pm$ $6.32,65.10 \pm 5.85,81.00 \pm 7.98$ or $89.54 \pm 9.20$ percent respectively. Addition of identical amounts of urine samples
Age, Sex and Pregnancy on Levels of Urinary Inhibitors
from male children between 7-13 years of age were found to inhibit the precipitation of $\mathrm{Ca}^{2+}$ and $\mathrm{HPO}_{4}{ }^{2-}$ ions as mineral phase by $15.89 \pm 2.09,27.54 \pm 1.79,42.67 \pm 5.65$, $54.43 \pm 7.12, \quad 63.09 \pm 6.40,80.00 \pm 7.65$ or $84.12 \pm 8.65$ and $14.56 \pm 2.02,26.09 \pm 2.12,39.71 \pm 4.48,51.21 \pm 5.95$, $59.56 \pm 6.97,75.56 \pm 8.43$ or $80.40 \pm 9.45$ percent respectively.

Table-1 Effect of urine samples from children between 713 years of age on in vitro Mineralization

\begin{tabular}{|c|c|c|c|c|c|}
\hline \multirow{3}{*}{ S.No } & \multirow{3}{*}{$\begin{array}{l}\text { Volume of } \\
\text { urine used } \\
\qquad(\mathrm{ml})\end{array}$} & \multicolumn{4}{|c|}{ Percent inhibition of ion precipitation } \\
\hline & & \multicolumn{2}{|c|}{ Female Subjects } & \multicolumn{2}{|c|}{ Male Subjects } \\
\hline & & Calcium & Phosphate & Calcium & Phosphate \\
\hline 1 & 0.1 & $\begin{array}{c}17.40 \pm \\
2.34\end{array}$ & $\begin{array}{c}14.82 \pm \\
1.98\end{array}$ & $\begin{array}{c}15.89 \pm \\
2.09\end{array}$ & $\begin{array}{c}14.56 \pm \\
2.02\end{array}$ \\
\hline 2 & 0.2 & $\begin{array}{c}30.54 \pm \\
4.32\end{array}$ & $\begin{array}{c}28.21 \pm \\
2.65\end{array}$ & $\begin{array}{c}27.54 \pm \\
1.79\end{array}$ & $\begin{array}{c}26.09 \pm \\
2.12\end{array}$ \\
\hline 3 & 0.3 & $\begin{array}{c}46.34 \pm \\
4,78\end{array}$ & $\begin{array}{c}43.78 \pm \\
4.39\end{array}$ & $\begin{array}{c}42.67 \pm \\
5.65\end{array}$ & $\begin{array}{c}39.71 \pm \\
4.48\end{array}$ \\
\hline 4 & 0.4 & $\begin{array}{c}56.87 \pm \\
6.98\end{array}$ & $\begin{array}{c}54.21 \pm \\
6.32\end{array}$ & $\begin{array}{c}54.43 \pm \\
7.12\end{array}$ & $\begin{array}{c}51.21 \pm \\
5.95\end{array}$ \\
\hline 5 & 0.5 & $\begin{array}{c}68.54 \pm \\
6.35\end{array}$ & $\begin{array}{c}65.10 \pm \\
5.85\end{array}$ & $\begin{array}{c}63.09 \pm \\
6.40\end{array}$ & $\begin{array}{c}59.56 \pm \\
6.97\end{array}$ \\
\hline 6 & 0.6 & $\begin{array}{c}88.45 \pm \\
7.21\end{array}$ & $\begin{array}{c}81.00 \pm \\
7.98\end{array}$ & $\begin{array}{c}80.00 \pm \\
7.65\end{array}$ & $\begin{array}{c}75.56 \pm \\
8.43\end{array}$ \\
\hline 7. & 0.7 & $\begin{array}{c}92.12 \pm \\
8.65\end{array}$ & $\begin{array}{c}89.54 \mathrm{v} \\
9.20\end{array}$ & $\begin{array}{c}84.12 \pm \\
8.65\end{array}$ & $\begin{array}{c}80.40 \pm \\
9.45\end{array}$ \\
\hline
\end{tabular}

All values are Mean \pm S.D of 5 replicates

In order to quantify the level of the urinary inhibitors, their levels in the urine samples were expressed in terms of Inhibitory Units (I.U).One Inhibitory Unit being the amount of urine which inhibited the precipitation of either $\mathrm{Ca}^{2+}$ or $\mathrm{HPO}_{4}{ }^{2-}$ ions as mineral phase by $50 \%$. The inhibitory units (I.U) thus calculated were expressed as I.U / dl of urine. Results presented in Table-2, demonstrate that on an average based on $\mathrm{Ca}^{2+}$ or $\mathrm{HPO}_{4}{ }^{2-}$ precipitation male and female children between 7-13 years of age were found to excrete $285 \pm 26$ or $260 \pm 19$ and $314 \pm 22$ or $280 \pm 21$ I.U / $\mathrm{dl}$ of urine respectively. The differences in I.U excreted / dl of urine were found to be insignificant at $p<0.5$. Identical results were obtained when studies were conducted on children having age less than 7 years of age (Table-3). 
Table 2 Excretion of Urinary Inhibitors of Mineralization* by the children of age between 7-13 Years

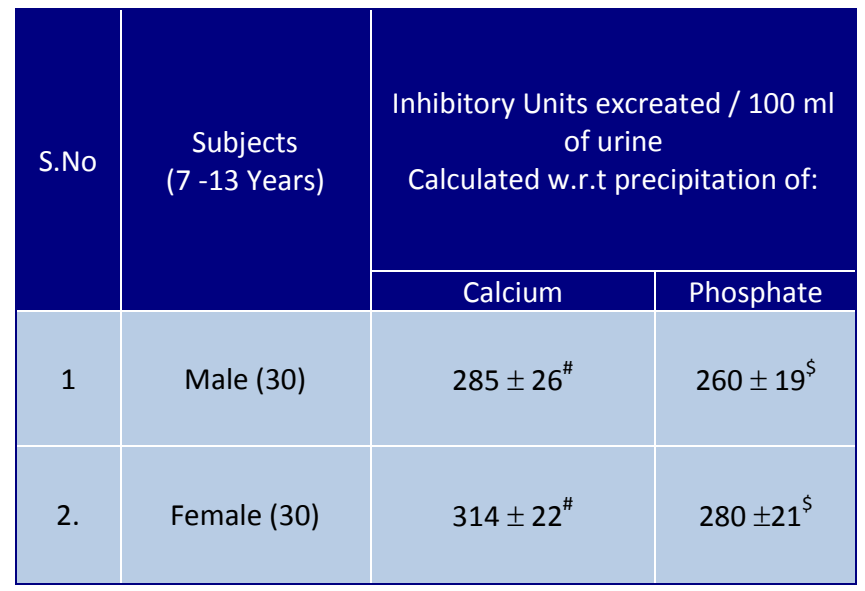

*Level of Urinary Inhibitors expressed in terms Inhibitory Units (IU). One IU is defined as the amount of Urine which inhibits the precipitation of either calcium or phosphate ions as mineral phase by $50 \%$.

All values are Mean \pm S.D

\# \& \$ differences in I.U were found to be insignificant at $\mathrm{p}<0.5$.

Table 3 Excretion of Urinary Inhibitors* by the children of age less than 7 years

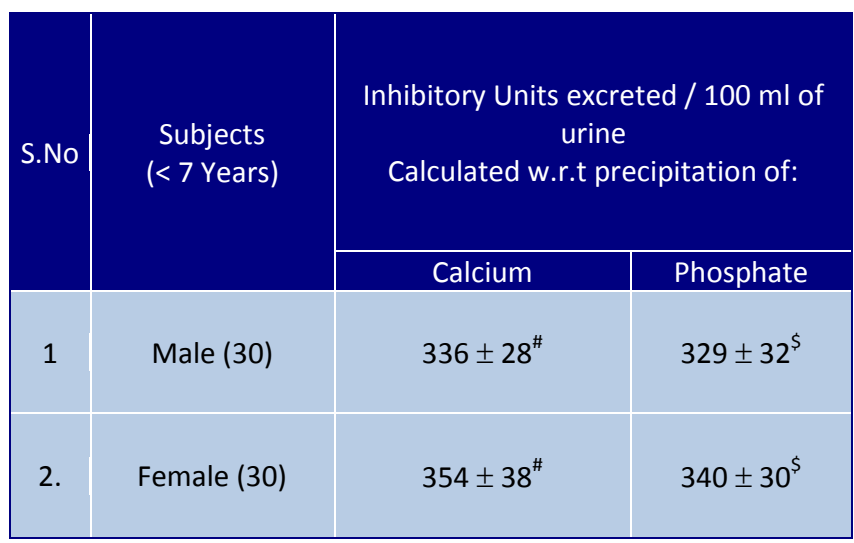

*Level of Urinary Inhibitors expressed in terms Inhibitory Units (IU). One IU is defined as the amount of Urine which inhibits the precipitation of either calcium or phosphate ions as mineral phase by $50 \%$.

All values are Mean \pm S.D

\# \& \$ differences in I.U were found to be insignificant at $p<0.5$.

Effect of pregnancy on the level of urinary inhibitors:

Results presented in Table- 4 demonstrate that during $1^{\text {st }}$, $2^{\text {nd }}$ and $3^{\text {rd }}$ trimester of pregnancy, based on $\mathrm{Ca}^{2+}$ or $\mathrm{HPO}_{4}{ }^{2-}$ precipitation, adult pregnant females (> 20 years of age) were found to excrete $315 \pm 32,292 \pm 27$ and $154 \pm 19$ or $285 \pm 38,242 \pm 31$ and $148 \pm 21 \mathrm{I} . \mathrm{U} / \mathrm{dl}$ of urine respectively. The differences between the $1^{\text {st }}$ and $3^{\text {rd }}$ trimester were found to be highly significant $(p<0.001)$.
Table 4 Effect of Pregnancy on the level of Urinary Inhibitors of Mineralization

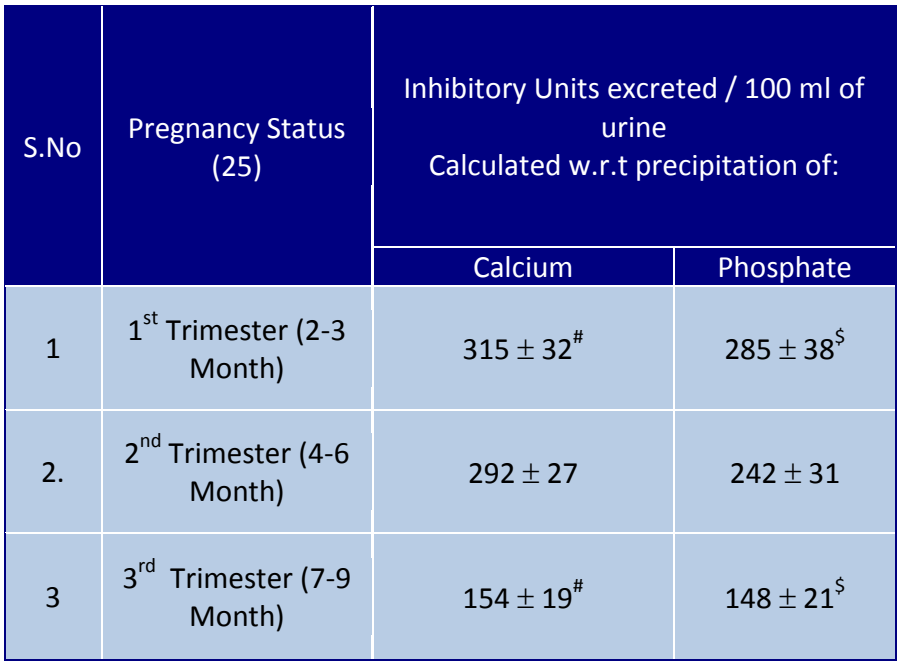

* Level of Urinary Inhibitors expressed in terms (IU). One IU is defined as the amount of urine which inhibits the precipitation of either calcium or phosphate ions as mineral phase by $50 \%$.

All values are Mean \pm S.D Inhibitory Units.

\# \& \$ differences between the $1^{\text {st }}$ and $3^{\text {rd }}$ trimester were found to be highly significant $(p<0.001)$.

\section{Discussion}

Relationship of level of urinary inhibitors with age, sex and urinary calculosis:

Studies have shown that the in vitro system of mineralization employed during the present studies can not only be used to study initial mineral phase formation (mineralization) i.e. precipitation of $\mathrm{Ca}^{2+}$ and $\mathrm{HPO}_{4}{ }^{2-}$ ions as mineral phase resembling hydroxyapatite in nature and the subsequent growth or demineralization of the pre-formed mineral phase but also the effect of various test samples on the above three processes ${ }^{24}$.

As early as 1958 based upon the ability of the urine samples obtained from normal persons and kidney stone patients to cause mineralization of the ricketic rat cartilage, Howard and his colleagues from John Hopkins ${ }^{25}$ called the urine from the normal subjects and kidney stone patients as "Good" and "Evil" urine respectively. Review of literature further demonstrated the following:

(i). Normal subjects excrete significantly higher levels of the inhibitors in their urine as compared to kidney stone patients of identical sex ${ }^{14-17}$.

(ii). As compared to the normal male adult persons ( i.e. $>20$ years of age), normal female adults excrete approximately 2-3 higher levels of urinary inhibitors which is in conformity with the epidemiological studies showing that adult males are at least three times more prone to renal calculosis as compared to adult females ${ }^{19}$.

(iii). The differences in urinary inhibitors between normal adult male and female subjects or normal subjects and kidney stone patients of identical sex are primarily due to the differences in the polypeptides having molecular weights between 2-16 thousand Daltons ${ }^{23}$. 
The above studies thus clearly suggest that the urinary inhibitors play an important role in the etiology of renal calculosis. Interestingly, in contrast to adult human beings, where males have been found to be at least three times more prone to renal calculosis as compared to adult females, equal tendency of renal calculosis has been reported in males and females during their childhood ${ }^{20}$. The results obtained during the present studies that up to 13 years of age no significant differences were found in the level of the urinary inhibitors between male and female children, provide an experimental proof to the epidemiological studies on the occurrence of renal calculosis problem in the children.

\section{Pregnancy status and Level of urinary inhibitors:}

In view of the well established fact that early development of skeleton is at its peak during the $3^{\text {rd }}$ trimester and virtually non significant skeleton development occurs during the $1^{\text {st }}$ trimester, the observation made during the present studies that as compared to the $1^{\text {st }}$ trimester, a highly significant $(p<0.001)$ decrease in the level of the urinary inhibitors occurred during $3^{\text {rd }}$ trimester of pregnancy. strongly suggests that the inhibitors may also have a role to play during physiological mineralization also.

Using identical system of in vitro mineralization, studies have shown that based on precipitation of $\mathrm{Ca}^{2+}$ or $\mathrm{HPO}_{4}{ }^{2-}$ ions as mineral phase, normal adult male and female subjects on an average were found to excrete $181 \pm 25$ or $166 \pm 27$ and $357 \pm 32$ or $300 \pm 30 \mathrm{I} . \mathrm{U} / \mathrm{dl}$ of Urine respectively. It is important to note that during the present studies it has been clearly shown that not only no significant differences exist in male and female children between 7-13 years of age but the level of the inhibitors in both the sexes of children are almost as high as present in the adult females. Interestingly, estrogens have been postulated to play a proactive role in renal calculosis in females by regulating the urinary excretion of citrate and oxalate ${ }^{19}$ thus strongly suggesting that sex hormones form an element of the regulatory mechanism.

\section{Conclusion}

Results obtained during the present studies along with what is already known in literature strongly suggest that urinary inhibitors of mineralization may be involved in the control of both Physiological and Pathological mineralization processes.

\section{Limitation of the studies:}

Since during the present studies, the level of the urinary inhibitors determined is based upon their ability to inhibit the precipitation of $\mathrm{Ca}^{2+}$ or $\mathrm{HPO}_{4}{ }^{2-}$ ions as mineral phase, the differences in the level of the inhibitors observed during the present studies can either be due to the differences in their concentrations or/and their activities.

\section{Relevance of the study:}

The study on the levels of urinary inhibitors in children provides experimental evidence to the epidemiological studies on the prevalence of renal calculosis that, in contrast to adults, both the sexes are equally prone to renal calculosis problem. The studies on the levels of urinary inhibitors in non pregnant and pregnant females (in $1^{\text {st }}, 2^{\text {nd }}$ and $3^{\text {rd }}$ trimester) suggests that the inhibitors have a role to play during physiological mineralisation also.

Future scope of the study:

Using standard biochemical and biophysical techniques, studies are in progress to isolate, purify and characterize the potent inhibitors obtained from urine samples of different subjects, so as to enable us to differentiate whether the differences observed are due to differences in their concentrations or activities.

\section{Author's Contribution:}

MK designed the study, acquired the data, deduced the data, drafted the manuscript, and revised it. RK planned the study with $\mathrm{MK}$, conducted the statistical data analysis, interpreted the data, and revised the manuscript. AKL and SKS interpreted the data and critically revised the manuscript. All the authors approved the final document.

\section{Acknowledgements:}

We are grateful to Professor Raj Kumar Jethi retired Professor, Department of Biochemistry, Punjab University, Chandigarh, India for all guidance, constant help and support in writing this paper We are also thankful to Himalayan Institute of Medical Sciences for providing us resources to conduct this study and for granting permission to publish this article.

\section{Conflict of interest:}

There is no conflict of interest among authors arising from the study.

\section{References}

1. Glimcher MJ. Molecular biology of mineralization in tissues with particular reference to bone. Revs. Med. Phys. 1959; 31: 359-93.

http://dx.doi.org/10.1103/RevModPhys.31.359

2. Khan SR, Shevock PN, Hackett RL. Urinary enzymes and calcium oxalate urolithiasis. J. Urol. 1989; 142: 846-9. PMid:2570167

3. Khan SR, Hackett RL. Role of organic matrix in urinary stone formation; an ultra structural study of crystal-matrix interface of calcium oxalate monohydrate stone. J. Urol. 1993; 150: 239-45.

PMid:8510264

4.Finalayson B. Physical and chemical aspects of urolithiasis. Kidney Int. 1978; 15: 442-8.

5. Rose GA, Wetsbury EJ. The influence of calcium content of water, intake of vegetables and fruit and of other food factors upon the incidence of renal calculi. Urol. Res. 1975; 3: 61-7.

http://dx.doi.org/10.1007/BF00256183

PMid:1162800

6. Daudon M, Dosimoni R, Hennequin C. Sex and age related composition of 10617 calculi analyzed by infrared spectroscopy. Uro. Res. 1995; 23:319-26. http://dx.doi.org/10.1007/BF00300021

PMid:8839389

7. Robertson WG, Peacock M, Nordin BEC. Activity product in stone forming and non-stone forming urine. Clin. Sci. 1968; 34: 579-94.

PMid:5666884 
8. Meyer JL, Fleisch H. Calcification inhibitors in rat and human serum and plasma. Biochem. Biophys. Acta. 1984; 799: 115-21.

http://dx.doi.org/10.1016/0304-4165(84)90284-8

9. Wesson JA, Woreecter EM, Kleinman JG. Role of anionic proteins in kidney stone formation: Interaction between model anionic polypeptides and calcium oxalate crystals. J. Urol. 2000; 163; 1343-8.

http://dx.doi.org/10.1097/00005392-200004000-00082 http://dx.doi.org/10.1016/S0022-5347(05)67775-0

10. Sivakamaundari P, Varalakshmi P, Kannabiran M. Nuclear pore complex oxalate binding protein p62: its expression on oxalate exposure to VERO cells. Cell Biochem. 2004; 93(6) 1099-106.

http://dx.doi.org/10.1002/jcb.20269

PMid:15449314

11. Talwar HS, Singla SK, Tandon C, Jethi RK. Nucleoside 5 phosphates on Collagen induced in-vitro mineralization. Indian J. Exptl. Biology.2004; 42(8): 844-6.

PMid:15573538

12. Zhao X, Yu G, Yur N, Guan H. Effects of low-molecular weight polyguluronate sulfate on experimental urolithiasis in rats. Urol. Res. 2007; 35: 301-6.

http://dx.doi.org/10.1007/s00240-007-0113-5

PMid:17929006

13. Turgut M, Unal I, Berber A, Demir TA, Mutlu F, Aydar Y. The concentration of Zinc, Magnesium and Manganese in calcium monohydrate stones appears to interfere with fragility in ESWL therapy. Urol. Res. 2008; 36: 31-8. http://dx.doi.org/10.1007/s00240-007-0133-1

PMid:18176803

14. Goldfarb DS. Increasing prevalence of kidney stones in the United States. Kid. Int. 2003; 63: 1951-2. http://dx.doi.org/10.1046/j.1523-1755.2003.00942.x PMid:12675877

15. Amato $M$, Lusini ML, Nelli F. Epidemiology of Nephrolithiasis . Urol. Int. 2004; 72: 1-5.

http://dx.doi.org/10.1159/000076582

PMid:15133324

16. Singla SK, Goel SC, Singh KP and Jethi RK. Anticalcifying properties of urine from normal persons and kidney stone patients. Indian J Med Res. 1978; 68:695-99. PMid:730242

17. Monica, Lal AK, Mishra A, Gupta H, Kakkar R. Study on the Role of Urinary Inhibitors of in-vitro ion precipitation in the aetiopathogenesis of renal calculosis. JIACM 2013; 14(2): 136-42.

18. Moghadam FM, Tandon C, Aggarwal S, Singla SK Singh SK and Jethi RK. Concentration of a potent calcium oxalate monohydrate crystal growth inhibitor in the urine of normal persons and kidney stone patients by ELISA based assay system employing monoclonal antibodies. J. of Cellular. Biochem. 2003; 90: 1261-75. http://dx.doi.org/10.1002/jcb.10671

PMid:14635198
19. Yoshihara H, Yamaguchi S, Yachiku S. Effects of sex hormones on oxalate-synthesizing enzymes in male and female rat livers. J. Urol. 1999; 161(2): 668-73. http://dx.doi.org/10.1016/S0022-5347(01)61992-X http://dx.doi.org/10.1097/00005392-199902000-00097

20. Parmar MS. Clinical Review- Kidney Stones. BMJ. 2004; 328: $1420-24$.

http://dx.doi.org/10.1136/bmj.328.7453.1420 PMid:15191979 PMCid:PMC421787

21. Tandon CD, Forouzandeh M, Aggarwal S and Jethi RK. Inhibitors of in vitro mineralization from flexor tendons of rabbits and their role in biological mineralization. Mol. And Cellular Biochem.1997; 171: 29-35.

http://dx.doi.org/10.1023/A:1006894400172

22. Baginski ES, Marie SS, Clark WL, ZAk B. Direct microdétermination of serum calcium. Clin. Chim. Acta. 1973; 14(1) : 46-9.

http://dx.doi.org/10.1016/0009-8981(73)90101-0

23. Amador E and Urban J. Simplified serum phosphorus analysis by continuous flow UV spectrophotometry. Clin. Chem. 1977; 18: 601-5.

24. Singla SK, Jethi RK. A simple method for the study of in vitro calculogeneisis. Ind. J. Exp. Biol. 1981; 19:282-285.

25. Howard JE, Thomas Jr. WC. Some observations on rachitic rat cartilage of probable significance in the etiology of renal calculi. Trans. Amer. Clin. Climat. Assoc. 1958; 70: 94-102.

\begin{tabular}{|l|c|}
\hline \multicolumn{2}{|c|}{ Article Information } \\
\hline \multicolumn{2}{|c|}{ Article history } \\
\hline Received & $1^{\text {nd }}$ July 2014 \\
\hline Received in revised form & $02^{\text {th }}$ August 2014 \\
\hline Accepted & $18^{\text {rd }}$ September 2014 \\
\hline
\end{tabular}

